\title{
Wind Loads on High-Rise Buildings by Using Five Major International Wind Codes and Standards
}

\author{
A. U. Weerasuriya and M.T.R. Jayasinghe
}

\begin{abstract}
A high-rise building of height - $183 \mathrm{~m}$ was employed to evaluate similarities and differences of wind load calculations done by using five major wind codes and standards. Evaluation was done in both ultimate and serviceability limit conditions. Member forces in columns, and beams, compressive stress in shear walls and support reactions obtained from finite element modelling was used to assess building responses in ultimate limit condition. Along and across wind, accelerations and drift indices were engaged to estimate serviceability limit state performances. Available 3 second gust wind speeds are converted into mean hourly and 10 minute average wind speeds to calculate wind loads on building. Wind speeds with 5 years return period was used in building acceleration calculation. The simultaneous use of higher terrain-height multiplier and importance factor may be lead to over design, even in cyclone prone areas. The use of post disaster wind speed does not exceed the drift limit but exceeds threshold acceleration value in across insert wind acceleration.
\end{abstract}

Keywords: Wind loading standards, Design wind speeds, Along-wind acceleration, Across-wind acceleration, Drift index

\section{Introduction}

High-rise buildings are more susceptible to wind loads due to their excessive heights, use of lightweight materials for super structure and inner partition walls, low structural damping, etc. Thus, design of high-rise buildings against wind loads is always a challenging task for designers. However, due to scarcity of land and high land cost, and for the glory of developer, building skyscrapers in urban areas is indispensable. In recent time, there has been a national trend to build tall, slender tower type high rise buildings in Sri Lanka especially in Colombo city limit [1].

A properly designed high-rise building should satisfy both ultimate and serviceability limit state conditions against vertical and lateral loads. To ensure a properly designed building, wind loading standards are serving as a primary design tool at early design stage in the absence of more sophisticated testing methods such as Wind Tunnel tests, Computational Fluid Dynamic (CFD) simulations, A proper wind loading standard would be able to calculate wind load fairly accurately and be able to check serviceability criteria by considering both static and dynamic behaviour of the building. However, early wind loading standards are not covering either dynamic analysis or serviceability limit criteria such as maximum allowable wind acceleration. In Sri Lankan context, neither the most common wind loading standard CP3 Chapter V-Part 2: 1972[2] nor the only available mandatory document on wind loading Design Manual-“Design buildings for high winds, Sri Lanka"[3] covers the above two aspects. Therefore, Sri Lankan engineers employ different international wind loading standards to calculate wind loads on high-rise buildings. However, direct adaptation of these international standards leads to some problems such as adaptability of country specific factors in Sri Lankan conditions, compatibility of wind loading standards with other design standards, achieved level of risk level remaining unknown, effects of differences and similarities of wind load calculations of different standards, satisfaction of serviceability conditions of a building, etc.

In this study, a $183 \mathrm{~m}$ tall office building was selected as a case study to compare wind load calculation done by using five major international wind loading standards. Those standards were selected on a rational basis by considering their popularity and familiarity in Sri Lanka. The differences and similarities of wind load calculations are addressed by using forces on structural members such as columns, beams, and shear walls obtained via finite element modelling (FEM).

In this paper section 2 explains the reasons for selected codes and standards; section 3 illustrates the case study. Section 4 and 5 show the results for ultimate and serviceability limit

Eng. A.U.Weerasuriya, B.Sc.Eng(Hons), M.Sc. (Moratuwa), AMIE(Sri Lanka), PhD candidate, Department of Civil and Environmental Engineering, Hong Kong University of Science and Technology, Hong Kong.

Eng. (Prof). M.T.R. Jayasinghe, B.Sc.Eng(Moratuwa), PhD (Cambridge), C.Eng, MIE(Sri Lanka), Professor, Department of Civil Engineering, University of Moratuwa. 
states. Finally section 6 makes a conclusion about advantages and disadvantages of selected wind loading standards and proposes a suitable wind loading standard to assess wind loads on buildings in Sri Lanka.

\section{Selected codes and standards for the study}

The selection of wind loading standards is mainly based on its ability to address dynamic response of a high-rise building. This is because of slenderness, low damping ratio and flow mechanisms such as vortex shedding which tend to cause high-rise building to excite dynamically. However, the most common wind loading standard use in Sri Lanka, CP3 Chapter V-Part2:1972[2] could not be used to calculate wind loads on dynamically excited buildings as it employs a quasi-static approach. Therefore, many other international standards such as BS 6399.2:1997 [4], AS 1170.2:1989[5], AS/NZS 1170.2:2002[6] and EN 1991-1-4:2005[7] are used to design high-rise buildings in Sri Lanka.

The new British standard BS 6399.2:1997[4] uses equivalent static method with an augmentation factor to evaluate dynamic behaviour of highrise buildings up to $200 \mathrm{~m}$ height. In addition to the augmentation factor, there are provisions given to calculate design wind speed and pressure coefficients for dynamic analysis. The building and terrain height factor $\left(S_{b}\right)$ defined in this standard can be used to convert 3 second gust wind speed to mean hourly wind speed [8] AS 1170.2:1989[5] standard has a detailed method for dynamic analysis, which can be used for a building with height or length-tobreadth ratio greater than 5 and a first- mode of vibration of less than $1 \mathrm{~Hz}$. By using the gust factor method, this standard encounters most of the dynamic nature of wind such as resonance factor, background factor, damping ratio, peak factor for both approaching wind and the building, size of the building and spectrum of the approaching wind. This standard employs a 3-second gust wind speed as the basic wind speed which allows adopting this code directly in Sri Lankan context. Instead of using gust factor, AS/NZS 1170.2:2002 [6] uses aerodynamic shape factor and dynamic response factor to analysis dynamic behaviour of high-rise buildings. The Aerodynamic shape factor adjusts factors such as correlation of pressure on opposite sides of a building, load shearing effects between adjacent areas, local pressure effect, etc. The dynamic factor considers encountering different characteristics of dynamic behaviour of the building and dynamic nature of the approaching wind. The basic wind speed used in latest Australian standard is mean hourly wind speed. The Euro standard, EN 1991-1-4:2005[7] is the first real multinational wind loading standard. In this study it is used with the National annex prepared for United Kingdom. The dynamic nature of the wind loading is captured via structural factor, which takes in to account the effect on wind actions from the nonsimultaneous occurrence of peak wind pressures on surfaces together with the effect of the vibrations of the structure due to turbulence.

Comparison of wind loading standards is a common objective accomplished by researchers before adopting them directly in any country other than its origin. Bashor and Kareem [9] compared six major international wind loading standards for both ultimate and serviceability limit states to identify parameters for further theoretical studies. A series of papers was published in Asia Pacific Conference of Wind Engineering (APCWE) to harmonize different international wind loading standards used in Asia-Pacific countries ([10], [11], [12]). These studies employed base shear, bending moments and acceleration at the top of the building for the comparison purpose. Results of the comparison revealed that wind loads calculation using different codes and standards have significant discrepancies though they are evaluated for the same wind climate conditions. Aforementioned

\section{Case studies}

A $183 \mathrm{~m}$ high Commonwealth Advisory Aeronautical Research Council (CAARC) standard building model [13] was selected as the case study for wind load calculation. The plan dimension of this building is $46 \mathrm{~m} \times 30 \mathrm{~m}$ which gives height-to-breadth ratio $6.1(>5)$ anticipating dynamic excitation due to wind loads. The same building model was used by previous researchers $[10,11,12]$ to compare wind loads derived by using wind loading standards. For the load calculation purpose, this building is assumed as an office in an urban area of Sri Lanka. It is also designed as a 51 storey building with floor-to-floor height of $3.6 \mathrm{~m}$. To represent the realistic structural behaviour, structural elements and internal spaces are designed in details. The basic structural form is wall-frame structure. The columns and beams form the frame and shear walls located around the lift and service core. 
Within the service core a hard zoning lift system, washrooms and ducts are located. The dimensions of structural members designed according to vertical loads are given in Table 1.

A general purpose finite element computer program SAP 2000 [14] was used to model the $183 \mathrm{~m}$ building in order to obtain member forces for comparison. SAP2000 is object-based modelling software which automatically converts the object-based model into an element-based model that is used for analysis. This element-based model is called the analysis model and consists of traditional finite element objects such as frame elements, shell elements and joints (nodes). A frame element with 6 degree of freedom is modelled as a straight line, connecting two points which has its own local axis to define section properties, loads and displacements. Frame elements can carry axial forces, shear and bending forces. Thus, frame members are used to model columns and beams. Shell elements that are used for shear walls and slabs are 4 node elements with membrane and plate-bending behaviour. For the slab, diaphragm constraint was used to preserve membrane action. Other than dead load of structural members, super imposed and live loads were applied in the model according to the BS6399: Part 1: 1996 [15]. Wind loads on building are applied with respect to wind flow in two orthogonal directions as joint loads at the column - beam junctions on the wind ward and leeward faces separately (Figure 1 (a) and (b)).

The accuracy of the FEM model was checked by using fundamental frequency of the model and provision given in Australian standards. Both Australian standards define fundamental frequency as

$n_{1}=\frac{46}{h}[H z]$ .$E q(1)$

Where, $\mathrm{h}$ is the building height.

The calculated fundamental frequency is 0.2513 $\mathrm{Hz}$. The first translation mode of the FEM model is $0.2197 \mathrm{~Hz}$ shows good aggreement with the calculated fundamental frequency. The slight descripancy may be due to loading and material properties assumed in FEM modelling. Other than that, it can be persumed that FEM model is accurate enough to obtain results for further analysis.

Table 1- Dimensions of structural elements in $183 \mathrm{~m}$ height building (all dimensions are in millimetres)

\begin{tabular}{|l|l|l|l|l|l|}
\hline $\begin{array}{l}\text { Structural } \\
\text { member }\end{array}$ & $\begin{array}{l}\text { Ground floor }- \\
10^{\text {th }} \text { floor }\end{array}$ & $\begin{array}{l}11^{\text {th }} \text { floor }-20^{\text {th }} \\
\text { floor }\end{array}$ & $\begin{array}{l}21^{\text {st }} \\
\text { floor }\end{array}$ & $\begin{array}{l}31^{\text {st }} \text { floor }-30^{\text {th }} \\
\text { floor }\end{array}$ & $\begin{array}{l}41^{\text {st }} \\
\text { floor }\end{array}$ \\
\hline Column & $1050 \times 1050$ & $950 \times 950$ & $800 \times 800$ & $700 \times 700$ & $500 \times 500$ \\
\hline Shear wall & 300 thickness & 250 thickness & 200 thickness \\
\hline Beam & $600 \times 400$ (depth $\times$ width) \\
\hline Slab & 175 thickness \\
\hline
\end{tabular}

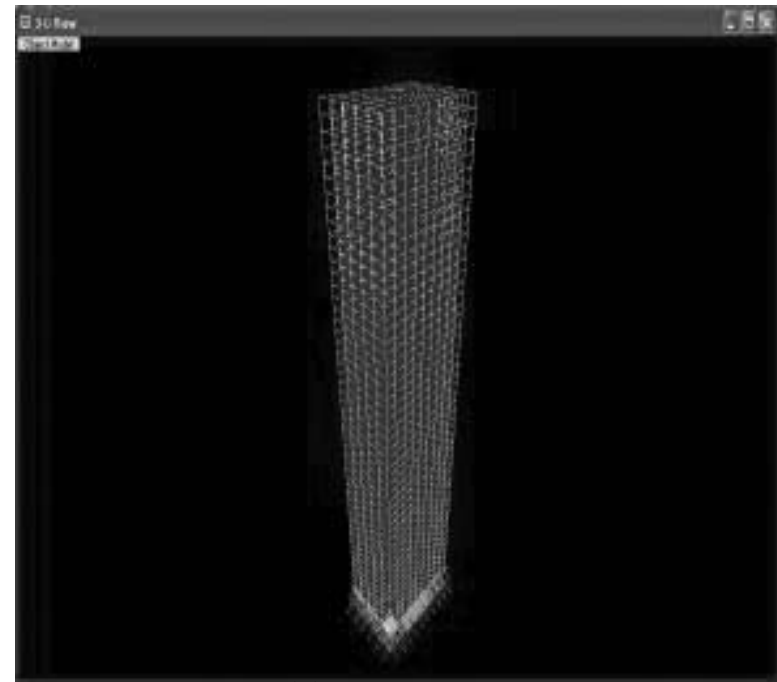

(a)

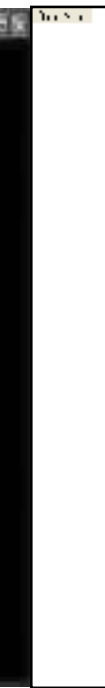

Figure 1 - Finite element 3 - D models of (a) 3-D view of $183 \mathrm{~m}$ height building (b) wind loads applied on windward and leeward sides of the building separately.

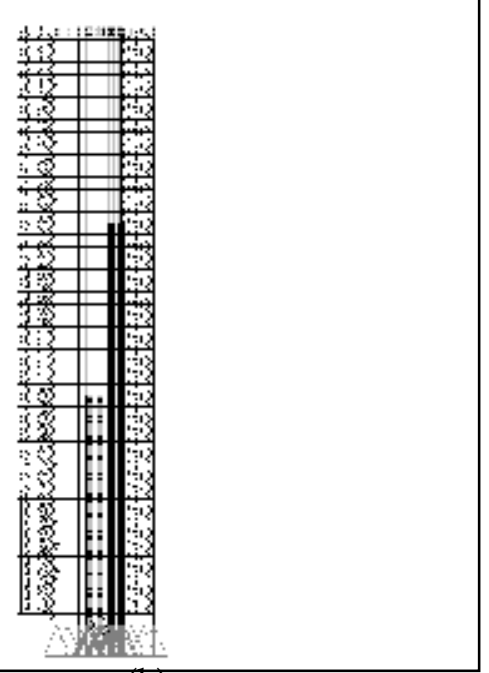

(b) 


\section{Basic wind speeds with different averaging time}

The provisions of wind load calculation given in different wind loading standards are based on basic wind speeds with different averaging times. These averaging times are range from 3 second to 1 hour. However, the only available wind speed data in Sri Lanka are based on 3 second gust wind speed. Therefore, it is necessary to convert 3 second gust wind speeds into different averaging time wind speeds by using proper conversion factors. This conversion should be done cautiously as erroneous conversion might lead to have unrealistic wind loads. For this study, conversion was done as follows.

First, 3 second gust wind speed is converted in to mean hourly wind speed as proposed by Cook [8] (Eq 1). This method is based on the terrain and building height factor given in BS
6399 - 2:1997[4]. One of the advantages of this method is that it can accommodate site and building characteristics such as the distance away from sea.

$V_{\text {mean }}=V_{G} / S_{b}$

Where, $V_{G}$ is the available 3 second gust wind speed. $S_{b}$ is the site and building height factor for $10 \mathrm{~m}$ height in an open terrain as defined in Table 04 of BS 6399 - 2:1997[4] for standard method.

The conversion factor 1.06 is used to convert mean hourly wind speeds to 10 minute mean speed, as it was proposed by the Institute of Civil Engineers in United Kingdom (ICEUK) [16]. The wind speeds in all three zones with different average times are shown in Table 1.

Table 2 - Basic wind speeds with different averaging time

\begin{tabular}{|c|c|c|c|c|c|c|}
\hline & \multicolumn{2}{|c|}{ Zone $1\left(\mathrm{~ms}^{-1}\right)$} & \multicolumn{2}{|c|}{ Zone $2\left(\mathrm{~ms}^{-1}\right)$} & \multicolumn{2}{|c|}{ Zone $3\left(\mathrm{~ms}^{-1}\right)$} \\
\hline & 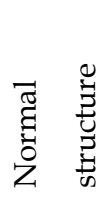 & 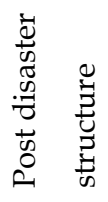 & 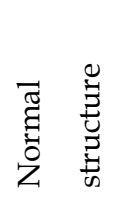 & 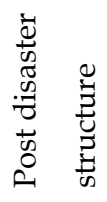 & 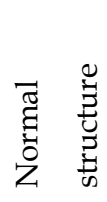 & 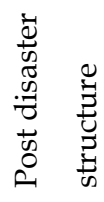 \\
\hline $\begin{array}{l}\text { CP } 3 \text { : Chapter V : Part } 2: 1972 \\
\text { (3 second gust wind speed) }\end{array}$ & 49 & 54 & 43 & 47 & 33 & 38 \\
\hline $\begin{array}{l}\text { BS } 6399-2: 1997 \\
\text { (Mean hourly wind speed) }\end{array}$ & 27 & 30 & 24 & 26 & 18 & 21 \\
\hline $\begin{array}{l}\text { BS EN 1991-1-4:2005 } \\
\text { (10 minutes mean wind speed) }\end{array}$ & 28 & 32 & 25 & 28 & 19 & 22 \\
\hline $\begin{array}{l}\text { AS } 1170.2 \text {-1989 } \\
\text { (3 second gust wind speed) }\end{array}$ & 49 & 54 & 43 & 47 & 33 & 38 \\
\hline $\begin{array}{l}\text { AS/NZS 1170.2:2002 } \\
\text { (3 second gust wind speed) }\end{array}$ & 49 & 54 & 43 & 47 & 33 & 38 \\
\hline
\end{tabular}

\section{Wind induced forces}

Wind loading standards only facilitate calculation of wind pressures on building faces at different heights. Multiplying calculated pressures with corresponding contributory areas will give the wind load at that height. However, this is not the actual load experienced by structural members as they have load sharing mechanisms. On the other hand structural members are designed by considering the actual loads acting on them rather than considering loads on the structure.

The actual structural load acting on any member can be obtained by using the 3-D finite element model by applying external loads. Post disaster wind speeds in all three zones as shown in Table 1 were used for wind calculation. The use of higher post-disaster wind speeds compared to low wind speeds for normal structures is recommended based on views of previous researchers ([17], [18]) considering; uncertainty of derivation of basic wind speeds, lower wind speeds compared to other countries with similar topographical and wind conditions, and as a conservative approach to achieve higher margin of safety, etc. Wind loads are calculated by using dynamic methods as given in standards to encounter anticipated dynamic response of the high-rise buildings. In addition to that, for wind load calculation by using AS 1170.2:1989[5] and AS/NZS 1170.2:2002[6] used higher terrain height multiplier in zone 1 to encounter higher 
cyclone risk of that area.The importance factor $\left(M_{i}=1.1\right)$ is also employed for AS 1170.2:1989[5] calculation in zone 1 to evaluate effect of use of $M_{i}$ together with higher terrain-height multiplier on wind load calculation.

Member forces used for the comparison of this study are maximum axial force, shear force and bending moment in columns, shear force and bending moment in beams, base moment and base shear at supports and maximum compressive stress in shear wall. The member forces are calculated for the following load combinations:

1. 1.2(Dead loads $[\mathrm{G}])+1.2($ Live load $[\mathrm{Q}])+$ 1.2(Wind load[W])

2. $1.0($ Dead loads $[\mathrm{G}])+1.4($ Wind load $[\mathrm{W}])$

3. $1.4($ Dead loads $[\mathrm{G}])+1.4($ Wind load $[\mathrm{W}])$ and

4. Wind load only $([\mathrm{W}])$.

For the purpose of comparison, the obtained results are shown as normalised forces with respect to CP 3 Chapter V- Part 2:1972[2], which is the most common practice in Sri Lanka. Wind induced forces such in columns, beams, supports and shells on $183 \mathrm{~m}$ high building in all three zones are shown in Figure 2 to 10.

\section{Results}

\subsection{Member forces}

The maximum loads in columns and beams are observed for the load combination $1.2 \mathrm{G}+1.2 \mathrm{Q}+1.2 \mathrm{~W}$. Thus it can be considered as the governing load combination for structural design. According to Figures 2(a) and (b), there is a significant difference between loads derived for Australian standards and rest of standards especially in zone 1 . The loads derived from Australian wind standards are much larger than loads derived from other standards in zone 1 . The maximum differences in bending moments in column and beams are 1.35 and 1.48 for wind flow perpendicular to $46 \mathrm{~m}$ side and 1.35 and 1.22 when wind flow perpendicular to $30 \mathrm{~m}$ side of the building.. For AS/NZS 1170.2:2002 maximum loads in column and beams are 1.16 and 1.4 respectively for wind flow perpendicular to $46 \mathrm{~m}$ side and 1.35 and 1.15 for wind flow perpendicular to 30 $\mathrm{m}$ side of the building. This is primarily due to the use of higher terrain-height multiplier in zone 1 contributed to larger wind load derivations of Australian standards. However, the substantial differences of loads between AS 1170.2:1989[5] and AS/NZS 1170.2:2002[6] arose from use of importance factor $\left(M_{i}=1.1\right)$ only for calculation done with AS 1170.2:1989[5]. This concludes that the use of higher terrain-height multiplier and importance factor together may lead to overestimate of wind loads even in cyclone prone areas. Therefore, designer can decide to employ either importance factor or terrain-height multiplier for a design unless necessary to design highly cyclone resilient structure such as cyclone shelter. The effect of different wind loads calculations are clearly visible of reults obtained for load combination $1.0 \mathrm{G}+1.4 \mathrm{~W}$, where effect of dead load is minimum. The larger wind loads resulted from Australian standards in zone 1 are again reflected from Figures3 (a) and (b). Column and beam loads obtained from zone 2 and zone 3 are approximtely same for all wind loading standards suggests that without using especial factors such as higher terrainheight multiplier,wind load calculations would be similar for all standards. However, the aforementioned fact should be closley inspected as member forces could be varied greatly not only in the use of especial factors but also the manner wind loads are applied on a building. For an example, the same load combination $1.0 \mathrm{G}+1.4 \mathrm{~W}$ displayed larger variation in zone 2 when wind flow perpendicular to $30 \mathrm{~m}$ building side (Figure 7). There are rather higher coulum and beam loads in zone 2 and 3 for both Euro and British standars (Figure 7). This might be resulted from wind load application method engaged by those two standards. The division-by-parts rule leads to applying higher wind loads over a height range compared to linear variation of wind load with height as assumed in CP 3 Chapter V: Part 2:1972[2]. Bending moments in coulum and beams reach a maximum for load case $1.4 \mathrm{G}+1.4 \mathrm{~W}$ due to the combine effect of higher dead load and wind loads. When wind flow perpendicular to $46 \mathrm{~m}$ side, the bending moments obtained for Australian standards can be as high as 1.85 and 1.4 for columns and beams respectively (Figures 4(a) and (b)). When wind flow perpendicular to $30 \mathrm{~m}$ side, those corresponding values are 1.75 for coulmns and 1.4 for beams for both Australian standards(Figures 8(a) and (b)). Wind load only case represents the individual differences in wind load calculations and its application on buildings. From Figures 5(a) and (b), it reflects that effect of used of both important factor and higher terrain height multiplier in AS 1170.2:1989[5]. The combined effect of these two factors lead to have wind loads two times greater than wind loads derived from CP 3 Chapter V: Part 2:1972[2]. The importance factor alone may increase the wind laod about $50 \%$ in columns. More surprisingly, EN 1991-4:2005[7] yields higher wind loads compared to both BS 6399.2:1997 [4] 
and CP 3 Chapter V: Part 2:1972[2] due to the use of difference in wind load application and use of a new set of factor different from previous British standards. Particularly, the effect of the use of divison-by-parts rule is

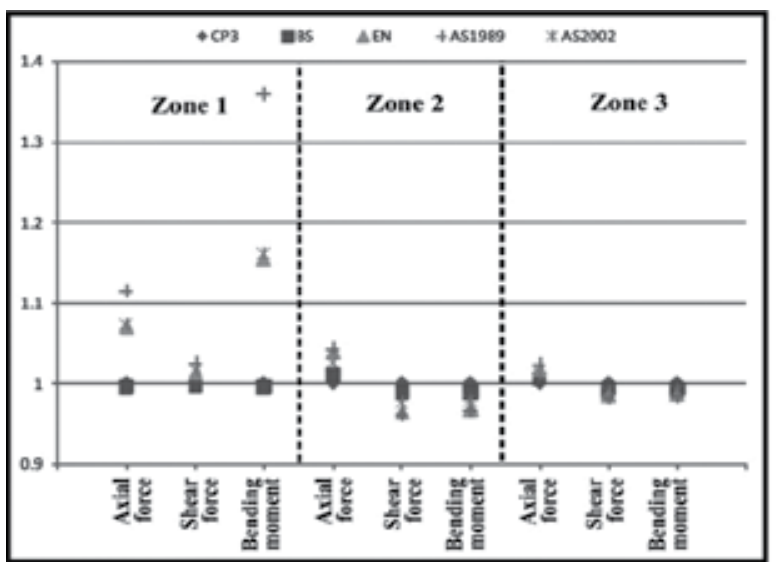

(a) displayed in results of Figures 9 (a) and (b). Both Euro standard and BS 6399.2:1997[4] yeild higher column and beam loads compared to CP 3 Chapter V: Part 2:1972[2].

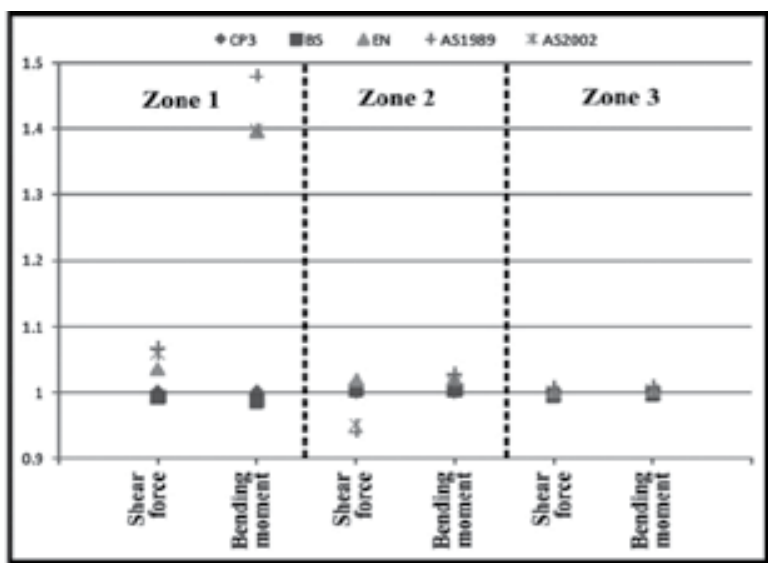

(b)

Figure 2 - (a) Column loads (b) Beam loads for load combination 1.2G+1.2Q+1.2W (wind flow perpendicular to $46 \mathrm{~m}$ long side)

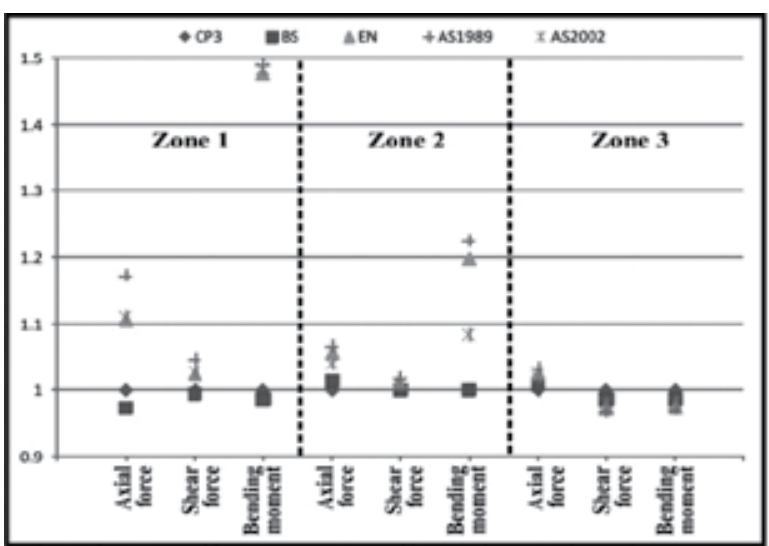

(a)

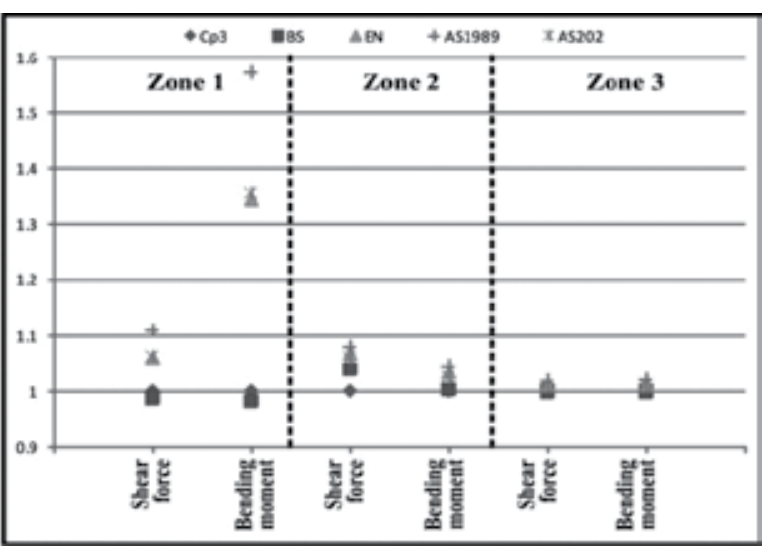

(b)

Figure 3 - (a) Column loads (b) Beam loads for load combination 1.0G+1.4W (wind flow perpendicular to $46 \mathrm{~m}$ long side)

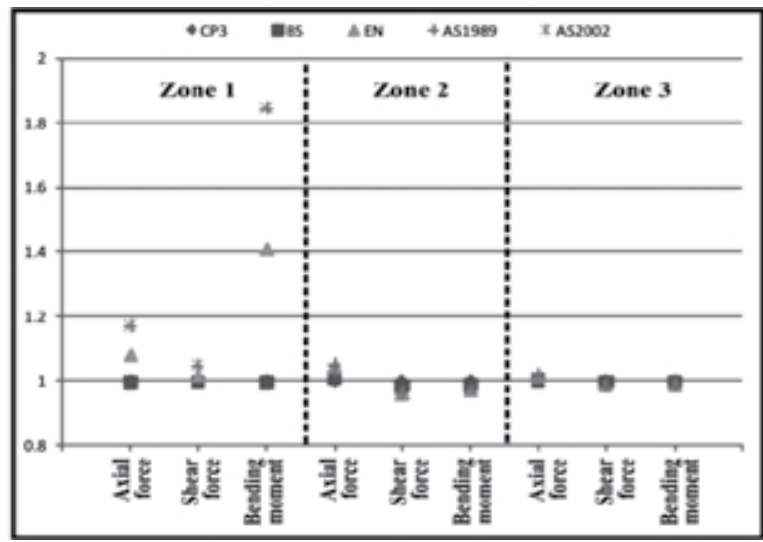

(a)

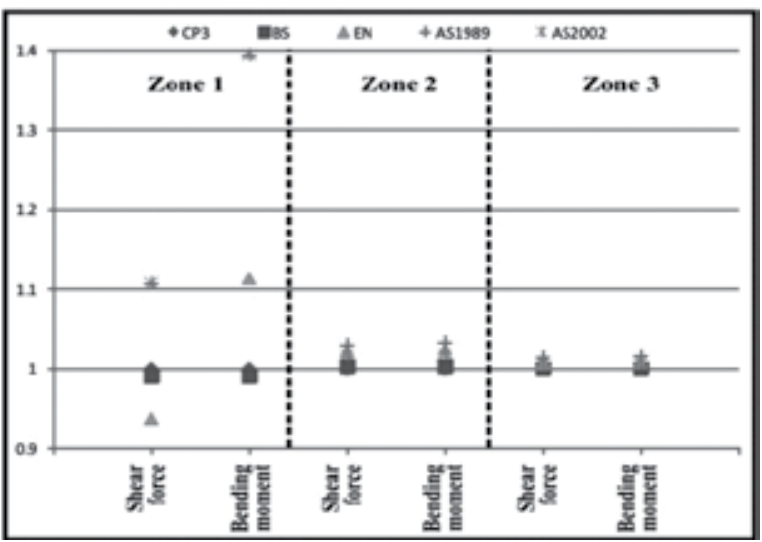

(b)

Figure 4 - (a) Column loads (b) Beam loads for load combination 1.4G+1.4W (wind flow perpendicular to $46 \mathrm{~m}$ long side) 


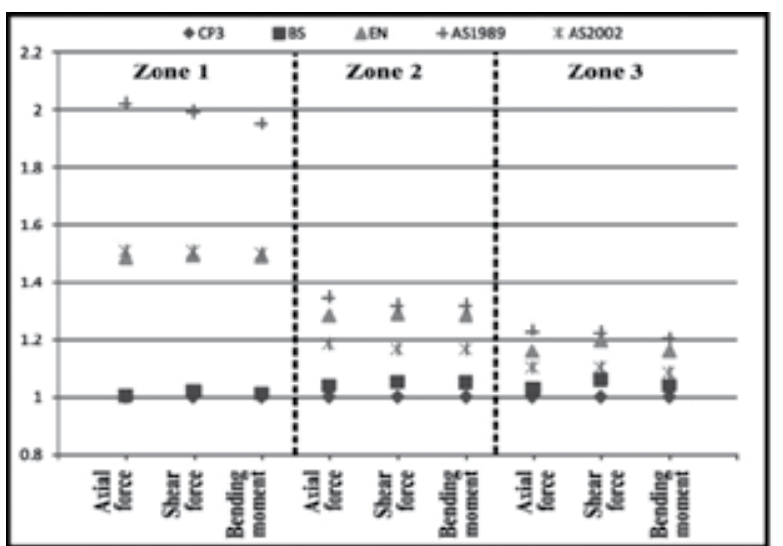

(a)

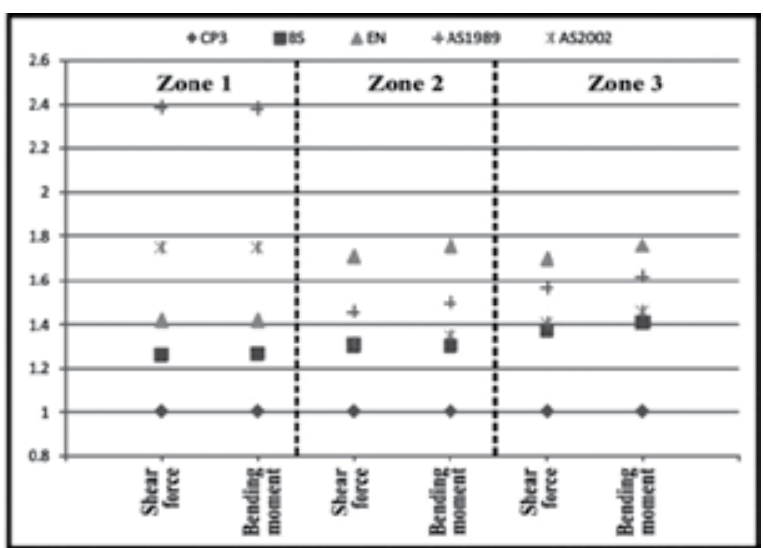

(b)

Figure 5 - (a) Column loads (b) Beam loads for wind load only (wind flow perpendicular to $46 \mathrm{~m}$ long side)

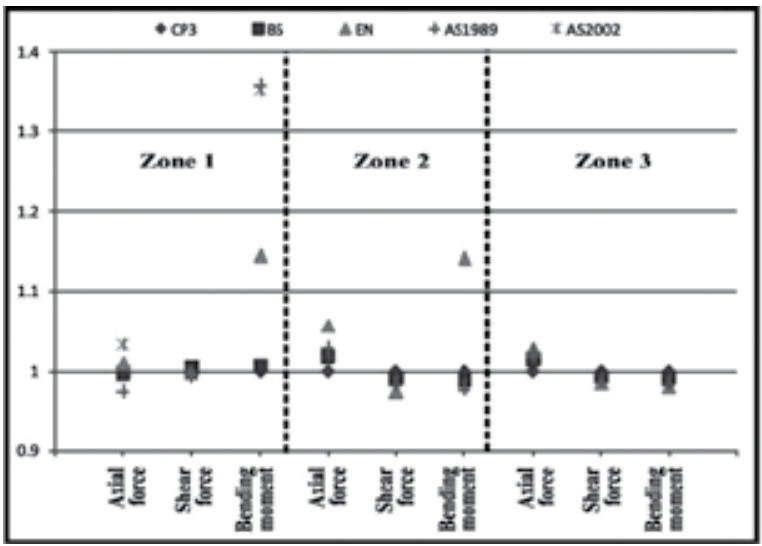

(a)

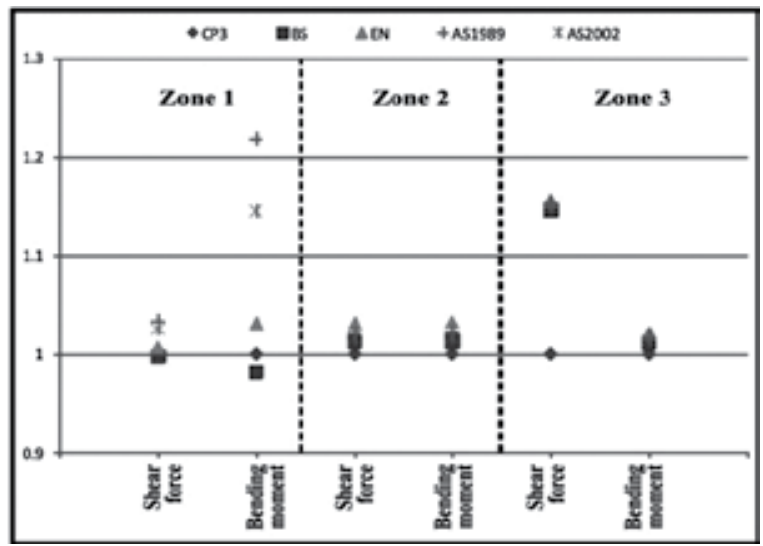

(b)

Figure 6 - (a) Column loads (b) Beam loads for load combination 1.2G+1.2Q+1.2W (wind flow perpendicular to $30 \mathrm{~m}$ long side)

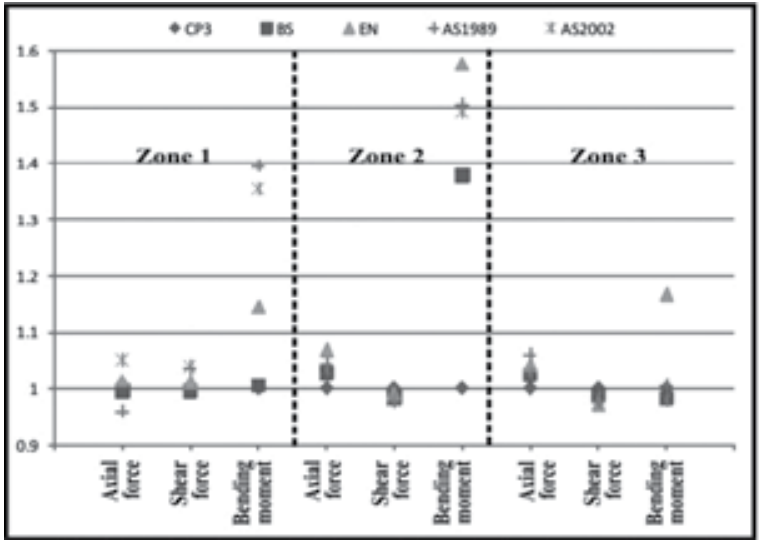

(a)

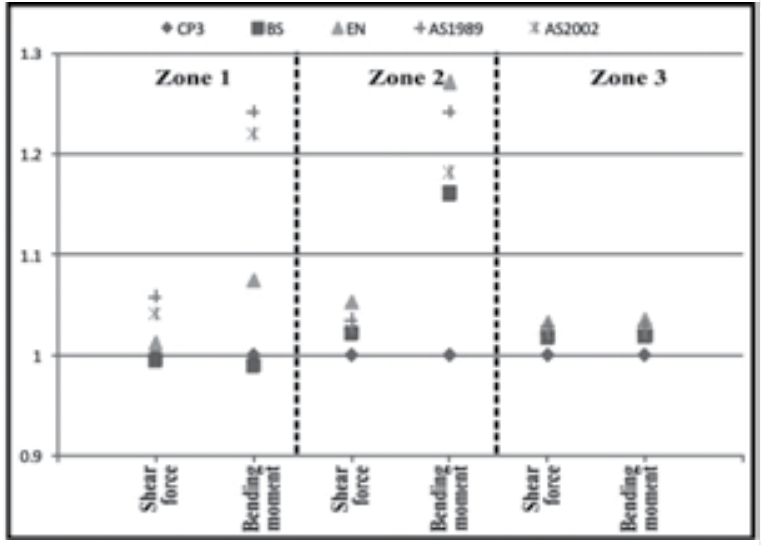

(b)

Figure 7 - (a) Column loads (b) Beam loads for load combination 1.0G+1.4W (wind flow perpendicular to $30 \mathrm{~m}$ long side) 


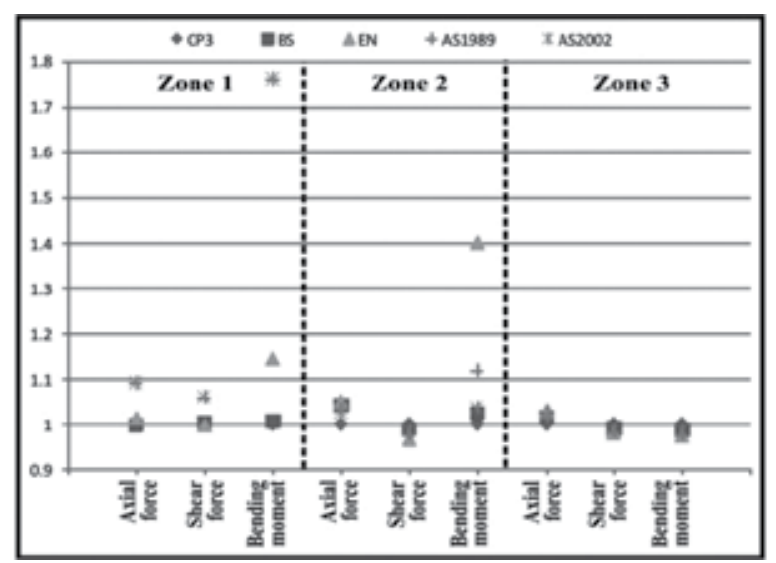

(a)

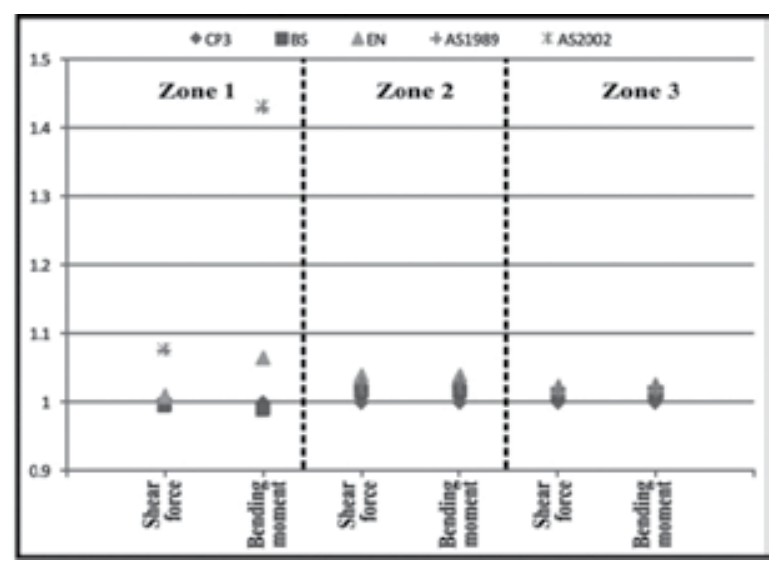

(b)

Figure 8 - (a) Column loads (b) Beam loads for load combination 1.4G+1.4W (wind flow perpendicular to $30 \mathrm{~m}$ long side)

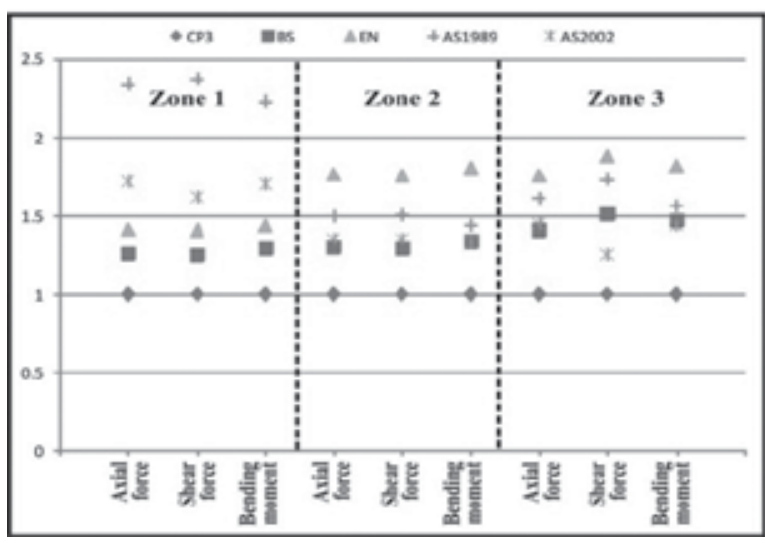

(a)

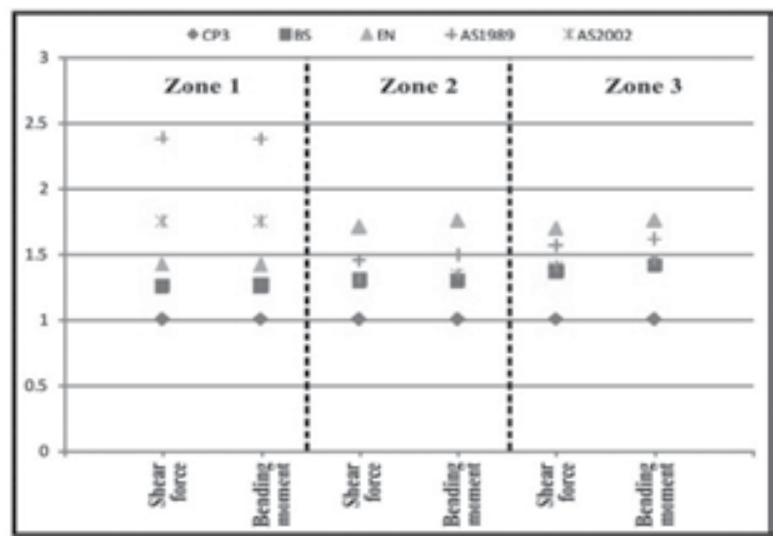

(b)

Figure 9 - (a) Column loads (b) Beam loads for wind load only (wind flow perpendicular to $30 \mathrm{~m}$ long side)

\subsection{Base reactions}

Base reactions are principal measurements of calculated wind loads and its overall effects on the building. Base shear represents the total wind loads on the building and base moment indicates overturning moment resulted from those wind loads. The latter factor is also an indirect indication of wind load distribution along the building height. Figures 10 (a) and (b) show bending moment and shear force in three zones for wind directions perpendicular to $46 \mathrm{~m}$ side and $30 \mathrm{~m}$ side respectively. The larger base moment and base shear yielded from AS 1170.2:1989[5] due to use of importance factor. In the zone 2 and zone 3, Euro codes yielded higher base moment as well as base shears values due to both higher wind load derivation and use of division-by-part rule for wind load disrtribution.
The maximum values 2.4 and 2.16 observed for base moment and base shear for AS 1170.2:1989[5]in zone 1 for wind flow perpendicular to $30 \mathrm{~m}$ side respectively. BS 6399.2:1997[4] has almost same values for base moment and base shear as CP3 Chapter V Part 2: 1972[2] values when wind flow perpendicular to $46 \mathrm{~m}$ long side. However, when wind flow perpendicular to $30 \mathrm{~m}$ side base moment and shear can be as high as1.6 and 1.8 in zone 1 and zones 2, 3 respectively. This is another evidence for difference arising from use of division-by-parts rule in newer British code compared to the previous British code of practice (Table 2). 


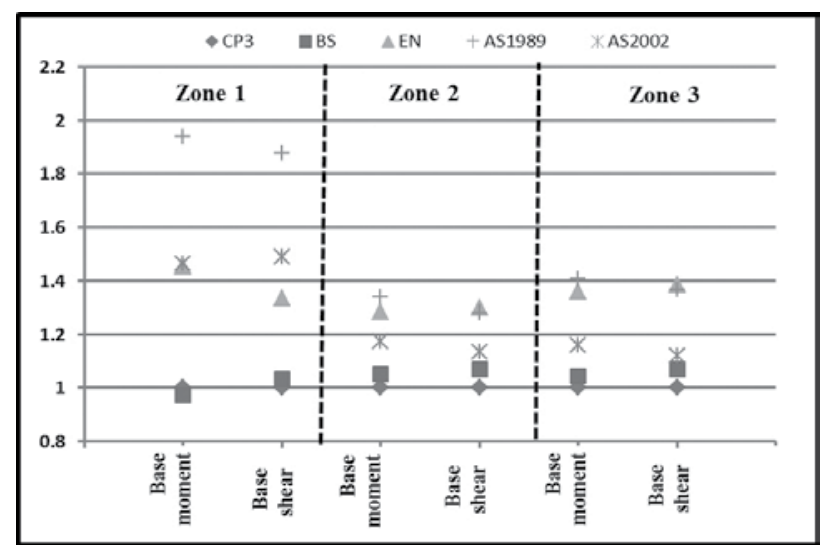

(a)

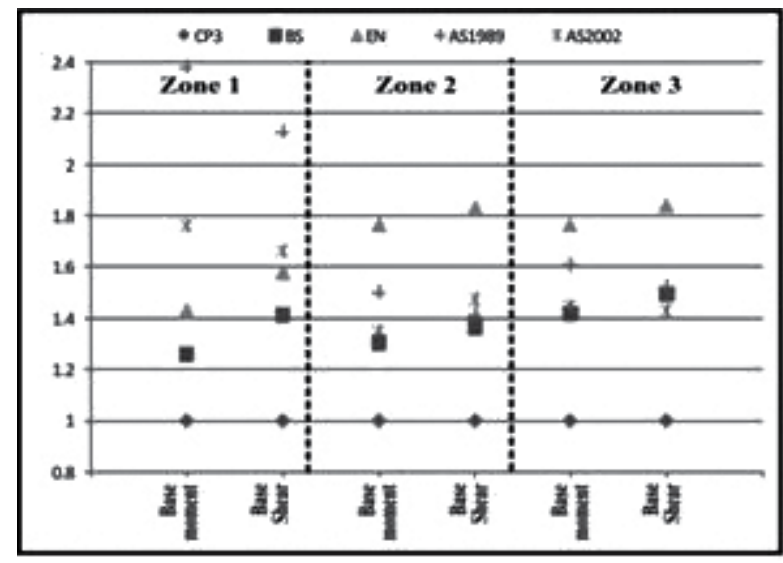

(b)

Figure 10 - Base moment and base shear of the $183 \mathrm{~m}$ building (a) Wind flow perpendicular to $46 \mathrm{~m}$ side (b) Wind flow perpendicular to $30 \mathrm{~m}$ side

Table 3 - Base moment and base shear of $183 \mathrm{~m}$ building for two orthogonal directions

\begin{tabular}{|l|l|l|l|l|l|l|}
\hline \multirow{2}{*}{ Wind loading standard } & \multicolumn{6}{|c|}{ Wind flow perpendicular to 46 m side } \\
\cline { 2 - 8 } & \multicolumn{5}{|c|}{ Base moment $(\times 106 \mathrm{Nm})$} & \multicolumn{3}{c|}{ Base shear $\left(\times 10^{3} \mathrm{~N}\right)$} \\
\cline { 2 - 8 } & Zone 1 & Zone 2 & Zone 3 & Zone 1 & Zone 2 & Zone 3 \\
\hline CP 3 Chapter V - Part 2:1972 & 2215.9 & 1478.8 & 966.7 & 21625.9 & 15502.9 & 10134.1 \\
\hline BS 6399.2:1997 & 2152.8 & 1554.8 & 1007.9 & 22329.1 & 16597.2 & 10829.3 \\
\hline AS 1170.2:1989 & 4296.7 & 1978.4 & 1358.6 & 40556.2 & 19856.4 & 13871.4 \\
\hline AS/NZS 1170.2:2002 & 3243.4 & 1734.0 & 1120.0 & 32218.2 & 17566.8 & 11345.2 \\
\hline BS EN 1991-1-4:2005 & 3220.4 & 1902.0 & 1315.0 & 28887.6 & 20157.4 & 14046.0 \\
\hline & \multicolumn{5}{|c|}{ Wind flow perpendicular to 30 m side } & \\
\hline CP 3 Chapter V - Part 2:1972 & 1103.5 & 772.5 & 463.8 & 11520.9 & 7934.9 & 4724.1 \\
\hline BS 6399.2:1997 & 1387.4 & 1007.9 & 657.4 & 16276.6 & 10828.5 & 7064.2 \\
\hline AS 1170.2:1989 & 2626.0 & 1159.9 & 745.6 & 24511.2 & 11187.2 & 7196.8 \\
\hline AS/NZS 1170.2:2002 & 1938.7 & 1037.8 & 669.7 & 19101.5 & 11659.1 & 6731.5 \\
\hline BS EN 1991-1-4:2005 & 1574.4 & 1363.6 & 817.6 & 18197.9 & 14512.0 & 8698.6 \\
\hline
\end{tabular}

\subsection{Maximum stress in shear walls}

Maximum compressive stress in shear walls can be observed for wind load derived by using AS 1170.2:1989[5]in zone 1 due to use of higher terrain height multiplier. The normalized maximum stress is about 1.7 and 1.45 for wind flow perpendicular to $46 \mathrm{~m}$ side and $30 \mathrm{~m}$ side of the building respectively. However, when wind flow perpendicular to $30 \mathrm{~m}$ side, Euro standards caused larger stress in shear walls in zones 2 and 3 because of higher wind loads acting on greater area of building sides due to use of divisio-by-part rule. Division-by-part rule also leads to generate higher wind loads, especailly wind flow perpendicular to $30 \mathrm{~m}$ side for BS 6399.2:1997[4] compared to CP3 Chapter V Part 2: 1972[2]. 


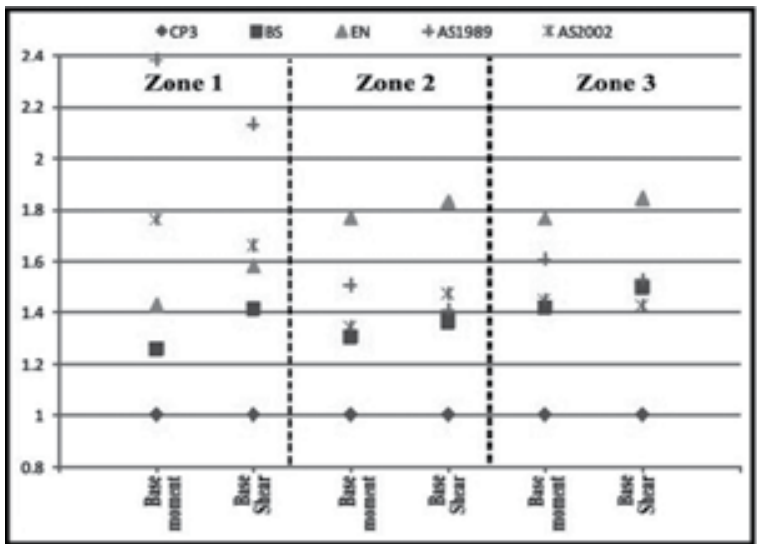

(a)

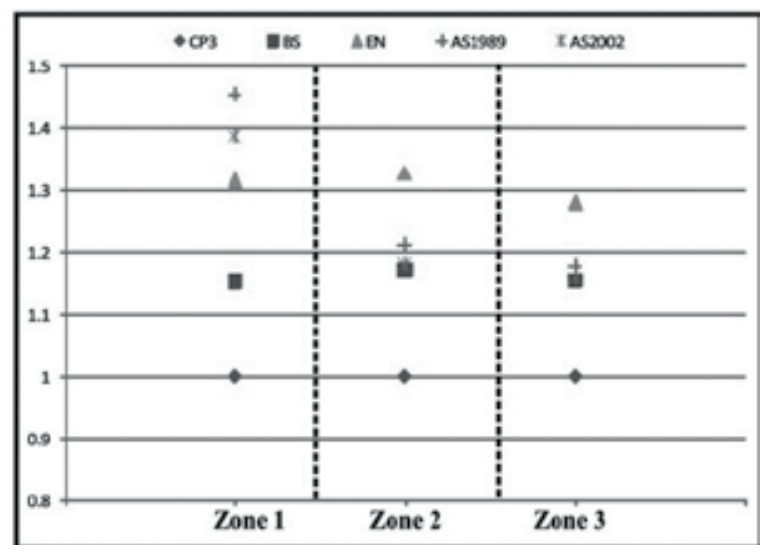

(b)

Figure 11 - Maximum shell stress in shear wall of the $183 \mathrm{~m}$ building (a) Wind flow perpendicular to $46 \mathrm{~m}$ wall (b) Wind flow perpendicular to $30 \mathrm{~m}$ wall

\subsection{Drift limit}

The drift limit is used to evaluate the degree of wind sensitivity of the building. This is an important measurement to prevent damages on non-structural building components including partition walls. The maximum deflection at top of the building in serviceability limit condition is obtained by applying wind loads to the finite element 3-D model.

According to the BS 8110-Part 2: 1985[19] the maximum allowable deflection is calculated as $h_{s} / 500$, where $h_{s}$ is the storey height of a single story building. The correspoding allowable deflection for $183 \mathrm{~m}$ height building is $366 \mathrm{~mm}$. The average drift index is defined as a ratio between maximum deflections to total height of the building. The calculated drift index values are shown in Table 3.

The generally accepted average drift index limit for high rise buildings is 1/500 [20]. By refering Table 3, only wind loads derived from AS 1170.2:1989 in zone 1 exceeds the generally accepted drift limit. This is because of larger wind loads resulted from use of both importance factor and higher terrain-height factor. However, all other cases satisfy the drift index requirement. In zone 3, all models well below the maximum drift limit, approximately by half of its threshold value. Thus, it can be concluded that even wind load calculation done by using post disaster wind speed will not cause conflict with drift index limit in tall buildings.

Table 4 - Drift index calculation for zone 1,2, and 3

\begin{tabular}{|l|c|c|c|}
\hline \multirow{2}{*}{ Wind loading standard } & \multicolumn{3}{|c|}{ Drift index } \\
\cline { 2 - 4 } & Zone 1 & Zone 2 & Zone 3 \\
\hline CP 3 Chapter V - Part 2:1972 & $1 / 961$ & $1 / 1250$ & $1 / 1785$ \\
\hline BS 6399.2:1997 & $1 / 935$ & $1 / 1219$ & $1 / 1754$ \\
\hline AS 1170.2:1989 & $1 / 425$ & $1 / 862$ & $1 / 1471$ \\
\hline AS/NZS 1170.2:2002 & $1 / 565$ & $1 / 1020$ & $1 / 1562$ \\
\hline BS EN 1991-1-4:2005 & $1 / 561$ & $1 / 1010$ & $1 / 1538$ \\
\hline
\end{tabular}

\section{Along wind and cross wind acceleration of the building.}

Only Australian and Euro code facilitate to calculate acceleration at top of the building. Euro code provides a method to calculate only along wind acceleration, while Australian standards offer methods to calculate both along wind and cross-wind accelerations. The standard deviation of acceleration at height ' $z$ ' is defined in EN 1991-4:2005[7]

$$
\sigma_{a, x}=\frac{c_{f} \cdot \rho \cdot b \cdot l_{v}}{m_{l, x}} \cdot R \cdot K_{x} \cdot \Phi_{l, x}(z)
$$

Where,

$\mathrm{C}_{\mathrm{f}}$ - force coefficient

$\rho$ - air density

$b$ - width of the structure 
$l_{v}\left(z_{s}\right)$ - turbulence intensity at the height $\mathrm{z}=\mathrm{z}_{\mathrm{s}}$ above ground

$R$ - square root of resonant response

$K_{x}$ - the non dimension coefficient obtained from chart given in Annex B of the code.

$m_{1, \mathrm{x}}$ - along wind fundamental equivalent mass

$n_{1, x^{-}}$fundamental frequency of along wind vibration of the structureestimated as

$n_{1}=\frac{46}{h}[H z]$

where $h$ is the height of the structure

Australian standards use 5 years return period wind speeds to calculate along wind and cross wind accelerations. The serviceability wind speeds with 5 year return peridod were derived from mean hourly wind speeds with 50 year return period by using probabilistic factor $\left(\mathrm{S}_{\mathrm{p}}\right)$ proposed in BS 6399.2:1997 as.

$$
S_{p}=\sqrt{\frac{5-\ln (-\ln (1-Q))}{5-\ln (-\ln 0.98)}}
$$

Where, $Q$ is the annual risk exceedance equals to 0.2 for 5 year return period. Calculated serviceability wind speeds by using $S_{p}=0.85$ are shown in Table 3.

Table 5 - Wind speeds used for acceleration calculations

\begin{tabular}{|c|c|c|c|}
\hline \multirow{2}{*}{ Return period } & \multicolumn{3}{|c|}{ Wind speed $\left(\mathrm{ms}^{-1}\right)$} \\
\cline { 2 - 4 } & Zone 1 & Zone 2 & Zone 3 \\
\hline 50 - years & 54 & 47 & 38 \\
\hline 5 - years & 46 & 40 & 32 \\
\hline
\end{tabular}

Comparing Tables 3 and 1, it is clear that the service wind speedswith 5 years return period are closer to wind speed proposed for normal structures in the design manual "Design building for high winds-Sri Lanka" [3]. Not only calculated 5-year return period wind speeds are similar to 3-second gust wind speeds for normal structures but also comparable with values proposed in AS/NZS 1170.2:2002[6]. However, the derived value for zone 1 is higher than the value suggested in Australian standard for areas with same wind climate.

The along wind and cross wind can be calculated as Equation (4) and (5) according to the Australian standard..

$$
\begin{aligned}
& \ddot{\mathrm{x}}_{\max }=\frac{3}{m_{0} h^{2}} \frac{\rho_{\text {air }} g_{R} I_{h} \sqrt{\left(\frac{S E_{t}}{\zeta}\right)}}{\left(1+2 g_{v} I_{h}\right)} \\
& \left\{\begin{array}{l}
\left\{C_{\text {fig, windward }} \sum_{z=0}^{h}\left[v_{\text {des }, \theta}(z)\right]^{2} b_{z} z \Delta z\right\} \\
-\left\{C_{\text {fig, leeward }}\left[v_{\text {des }, \theta}(h)\right]^{2} \sum_{z=0}^{h} b_{z} z \Delta z\right\}
\end{array}\right\} \ldots . . . E q(4)
\end{aligned}
$$$$
\ddot{\mathrm{y}}=1.5 \frac{b g_{R}}{m_{0}}\left[\frac{0.5 \rho_{\text {air }}\left[V_{\text {des }, \theta}\right]}{\left(1+g_{v} I_{h}\right)^{2}}\right] K_{m} \sqrt{\left(\frac{\pi C_{f s}}{\zeta}\right) \ldots E q(5)}
$$

where,

$m_{0}$ - average mass per unit height, in $\mathrm{kg} / \mathrm{m}$ $\rho_{\text {air }}$ - density of air which shall be taken as 1.2 $\mathrm{kg} / \mathrm{m} 3$
$V_{d e s, \theta}(z)$ - building orthogonal design wind speeds as a function of height $\mathrm{z}$

$V_{d e s, \theta}(h)$ - building orthogonal design wind speeds evaluated at height $h$

$b_{z}$ - average breadth of the structure at the section at height $\mathrm{z}$

$\Delta z$ - height of the section of the structure upon which the wind pressure acts

$b$ - breadth of a structure, normal to the wind stream

$g_{R^{-}}$peak factor for resonant response $(10 \mathrm{~min}$ period) given by:

$=\sqrt{2 \log _{e}\left(600 n_{c}\right)} n_{c}=$ first mode natural

frequency of vibration of a structure in the crosswind direction, in Hertz

$g_{v^{-}}$peak factor for the upwind velocity

fluctuations, which may be taken as 3.7

$I_{h}$ - turbulence intensity

$K_{m}$ - mode shape correction factor for crosswind acceleration

$C_{f s}$ - crosswind force spectrum coefficient generalized for a linear mode shape

$\zeta$ - ratio of structural damping to critical damping of a structure

$E_{t^{-}}$spectrum of turbulence in the approaching wind stream

$S$-size reduction factor

The acceleration values calculated are shown in Table 4. Euro code yields higher along wind acceleration values than Australian standards. However these along wind acceleration values are much less than across wind acceleration values due to slenderness of $183 \mathrm{~m}$ height building. In most of the cases, these across- 
wind acceleration values exceed the threshold value $0.15 \mathrm{~ms}^{-2}$ with 5 year return period [21]. Even for higher wind speed value in zone 1, along wind acceleration values do not satisfy the threshold value set for human comfort. This means that, across wind acceleration would be a significant factor when designing a high-rise building in an urban area of Sri Lanka.

\section{Conclusion}

Major findings of this study can be concluded ed as

1. Structural loads are varying according to the wind loads derived from the standards. Both Australian standards give higher forces in zone 1 due to use of importance factor $\left(M_{i}\right)$ and/or use of higher terrain multiplier for cyclonic areas.

2. Base shear and base moments are two major measurements on determining the effects of wind loads, which directly combine with the wind load values and their distribution along the height of the building. Higher base moment and base shear are obtained from British and Euro codes because they use division by parts rule for contributing wind loads along the height of the building.
3. Division -by - parts rule trends to apply higher loads even at the lower heights of the buildings and subsequently results in higher base moments for the building. Therefore, it is better to choose small strips at intermediate levels rather than choosing larger strips.

4. Only wind loads calculated according to the AS 1170.2:1989 for $183 \mathrm{~m}$ high building in zone 1 exceed the drift limit. This could be a result of higher wind loads derived with the use of both importance factor (Mi) and the higher terrain multiplier for cyclonic areas.

5. Along wind accelerations values calculated from Euro code are higher than the those values calculated from Australian codes except in zone 1 . The higher serviceability wind speeds values ued for Astralian codes may be the reason for above difference.

6. Across wind acceleration values are considerably higher than the along wind acceleration values. Thus greater concern should give to control across wind acceleration when designing high-rise buildings in Sri Lanka.

Table 6 - Acceleration values at $183 \mathrm{~m}$ height in zone 1, 2 and 3

\begin{tabular}{|c|c|c|c|c|c|}
\hline \multirow[t]{2}{*}{ Zone } & \multirow[t]{2}{*}{ Wind direction } & \multirow{2}{*}{$\begin{array}{c}\text { Acceleration } \\
\text { type }\end{array}$} & \multicolumn{3}{|c|}{ Acceleration (ms-2) } \\
\hline & & & $\begin{array}{c}\text { AS 1170.2: } \\
1989\end{array}$ & $\begin{array}{c}\text { AS/NZS } 1170.2: \\
2002\end{array}$ & $\begin{array}{l}\text { BS EN 1991-1-4: } \\
2005\end{array}$ \\
\hline \multirow[t]{4}{*}{ Zone 1} & \multirow[t]{2}{*}{ Normal to $46 \mathrm{~m}$ side } & Along wind & 0.155 & 0.156 & 0.134 \\
\hline & & Cross wind & 0.239 & 0.233 & - \\
\hline & \multirow[t]{2}{*}{ Normal to $30 \mathrm{~m}$ side } & Along wind & 0.109 & 0.107 & 0.094 \\
\hline & & Cross wind & 0.227 & 0.221 & - \\
\hline \multirow[t]{4}{*}{ Zone 2} & \multirow[t]{2}{*}{ Normal to $46 \mathrm{~m}$ side } & Along wind & 0.076 & 0.078 & 0.080 \\
\hline & & Cross wind & 0.173 & 0.166 & - \\
\hline & \multirow[t]{2}{*}{ Normal to $30 \mathrm{~m}$ side } & Along wind & 0.051 & 0.052 & 0.058 \\
\hline & & Cross wind & 0.168 & 0.159 & - \\
\hline \multirow[t]{4}{*}{ Zone 3} & \multirow[t]{2}{*}{ Normal to $46 \mathrm{~m}$ side } & Along wind & 0.034 & 0.034 & 0.033 \\
\hline & & Cross wind & 0.118 & 0.116 & - \\
\hline & \multirow[t]{2}{*}{ Normal to $30 \mathrm{~m}$ side } & Along wind & 0.024 & 0.026 & 0.025 \\
\hline & & Cross wind & 0.106 & 0.093 & - \\
\hline
\end{tabular}




\section{Acknowledgement}

Authors of this paper like to express their gratitude towards National Disaster Management Center (NDMC), who provided financial support throughout this study. They also wish to thank the Civil Engineering Department of University of Moratuwa for facilitating this research.

\section{References}

1. Karunaratne, S. A., High Rise buildings in Colombo (Structural Engineer's View), Proceedings of the international conference on "Advances in Continuum Mechanics, Materials Science, Nano science and Nano technology: Dedicated to Professor Munidasa P. Ranaweera", University of Peradeniya, Sri Lanka, 2008. pp 291- 302

2. CP 3 Chapter V: 1972 , Code of basic data for the design of buildings chapter V. Loading, Part 2 Wind Loads, British Standard Institution, London

3. Design of Buildings for High Winds, Sri Lanka, Sri Lankan Ministry of Local Government, Housing and Construction, 1980

4. British standard: Loading for building- Part 2: Code of Practice for wind loads; BS 63992:1997, British Standard Institution, London

5. Australian standard for wind loads ; AS 1170.2:1989, Standards Australia, New South Wales

6. Australian and New Zealand standards: Structural design actions Part 2: wind actions; AS/NZS 1170.2:2002, Standards Australia, New South Wales

7. British Standard: Eurocode 1: Actions on Structures - Part1- 4: General actions - wind actions; BS EN 1991-1-4:2005, British Standard Institution, London

8. Cook, N. J., Wind loading, A practical guide to BS 6399-2 Wind loads for buildings, Thomas Telford, 1999

9. Bashor, R., Kareem, A., Comparative study of major international standards, The seventh AsiaPacific conference on wind ngineering(APCWEVII), Taipe, Taiwan, November 08-12,2008

10. Tamura, Y., Holmes, J. D., Krishna, P., Guo, Lu., Katsumura, A., Comparison of Wind Loads on Medium Rise Building According to the AsiaPacific codes/.standards, The seventh AsiaPacific Conference on Wind Engineering(APCWE-VII), Taipe, Taiwan, November 08-12,2008.
11. Holmes, J. D., Tamura, Y., Krishna, P, Wind Loads on Low, Medium and High-Rise Buildings by Asia - Pacific codes, The Fourth International Conference on advances in Wind and Structures (AWAS'08), Jeju, Korea, May 2931-,2008.

12. Holmes, J. D., Tamura, Y., Krishna, P., Comparison of Wind Loads Calculated by fifteen Different Codes and Standards, for Low, Medium and High-Rise Buildings, 11th American Conference on Wind Engineering, San Juan, Puerto Rico, June 22-26, 2009.

13. Wardlaw, R. L., Moss, G. F., A Standard Tall Building Model for the Comparisons of Simulated Natural Winds in the Wind Tunnels, 3rd International Conference on Wind Effects on Buildings and Structures, Tokyo, Japan, 1971

14. CSI Analysis Referenc e Manual, Computers and Structures Inc., Berkeley, California, USA, 2013

15. British Standard: Loading for buildings Part 1 . Code of practice for dead and imposed loads; BS 6399-1:1996, British Standard Institution, London

16. Narayan, R. S, Cook, N. J., Smith, B. W., Rees, E. J., Blackmore, P., Report on the Calibration of Euro code for wind loading (BS EN 1991 - 4) and its UK National Annex against the current UK wind code (BS 6399: Part 2:1997), Report submitted to Department for Communities and Local Government (DCLG), UK, 2007

17. Wijeratne, M. D., Jayasinghe, M. T. R., "Wind Loads for High-Rise Buildings Constructed in Sri Lanka", Transactions Part 2- Institution of Engineers, Sri Lanka, 1998, pp 58-69

18. Premachandra, W. R. N. R., "Study of New Wind Loading Code to be Adopting on Sri Lanka", M.Sc Thesis, Graduate school, Kasetsart University, 2008

19. British Standard: Structural use of concrete- Part 2: Code of practice for special circumstances; BS 8110- 2:1985, British Standard Institution, London

20. Mendis, P., Ngo, T., Hariots, N., Hira, A., Samali, B., Cheung, J., Wind Loading on Tall buildings, EJSE special issue; Loading on structures, 2007. pp 41-54

21. International Organization for Standardization, 2007. Bases for design of structuresserviceability of buildings and walkways against vibration. Final DraftInternational Standard ISO/FDIS 10137:2007(E), Geneva, Switzerland 